\title{
GÊNERO E IDENTIDADE NO DESIGN DE BRINQUEDOS DO GRUPO LEGO ${ }^{\circledR}$
}

\author{
Jéssica Lane da Silva Oliveira \\ jessicalaneoliveira@gmail.com \\ Ana Paula Nazaré de Freitas \\ anapaulafreitas@uepa.br
}

Resumo: Este trabalho discute o papel do designer nos processo de construção de identidades de gênero através de uma análise da representação de características associadas a homens e mulheres em brinquedos do Grupo $\mathrm{LEGO}^{\circledR}$. Para isso, discutimos e problematizamos conceitos como cultura material, design, identidade e gênero. O objetivo foi analisar e compreender quais aspectos da morfologia dos brinquedos faziam representação e retratavam valores estereotipados de gênero em sua morfologia e discurso visual. Para isso realizamos uma análise dos discursos visuais e conceituais presentes nos produtos. Foram observados inicialmente a própria variedade de brinquedos do grupo LEGO, as embalagens, o material de divulgação, o esquema cromático e os conceitos que envolvem a representação dos gêneros, como: atividades, profissões etc. Como metodologia, trata-se de pesquisa descritiva e explicativa, pois pretendeu-se identificar, descrever e explicar os elementos que compõem um discurso de gênero presentes nos brinquedos. Para a delimitação de quais brinquedos seriam analisados foi realizada pesquisa documental, com objetivo de conhecer a história do grupo LEGO, seus produtos e identificar as linhas de produtos mais vendidos. Neste sentido foram definidas as linhas LEGO Friends ${ }^{\circledR}$ e LEGO City ${ }^{\circledR}$ para esta análise, por tratarem-se das linhas mais rentáveis do grupo, segundo dados divulgados pela empresa. Após as definições das linhas que seriam analisadas, foram elaboradas fichas de pesquisa que resultaram em quadros explicativos, que demonstram tanto o percentual de brinquedos da linha que se identificam como femininos e masculinos, quanto às características formais, os padrões cromáticos e conceituais dos brinquedos. Os brinquedos como parte da cultura material das sociedades contemporâneas é tido, muitas vezes, como objeto "inocente", algo muitas vezes destituído de um olhar crítico e esvaziado de significados duradouros. Porém, como objeto que permeia a infância consideramos importante lançar um olhar mais atento diante dos discursos representados por eles, pois muitos desses brinquedos controlam e definem os papeis sociais que as crianças devem desempenhar quando se tornarem. Essa delimitação de adequação do que se conforma como brinquedos femininos ou masculinos visa disciplinar os corpos, enquadrar comportamentos, padronizar e consequentemente construir uma determinada identidade para aquele sujeito. A análise dos 
produtos revelou que o Grupo LEGO reproduz estereótipos de gênero em seus brinquedos através de sua configuração formal e conceitual, segregando a brincadeira entre os meninos e as meninas, e contribuindo então para a manutenção de sistemas de opressão baseados no gênero. Esta monografia evidencia, portanto, que o designer, enquanto executor de atividade de planejamento e projetação está profundamente envolvido na interação entre as representações de gênero expressas pelos brinquedos LEGO e o processo de formação de identidades de gênero, pois dá forma, através dos produtos, às expectativas sobre diferentes grupos sociais.

Palavras-chave: Design, Epistemologia do Design, Gênero, Design de Brinquedos. 